(c) American Dairy Science Association, 2004.

\title{
Grain Processing, Forage-to-Concentrate Ratio, and Forage Length Effects on Ruminal Nitrogen Degradation and Flows of Amino Acids to the Duodenum
}

\author{
W. Z. Yang and K. A. Beauchemin \\ Sustainable Production Systems Section, Research Centre, \\ Agriculture and Agri-Food Canada, Lethbridge, AB, T1J 4B1, Canada
}

\section{ABSTRACT}

The objectives of this study were to evaluate effects of dietary factors that alter ruminal fermentability on rumen $\mathrm{N}$ degradation, microbial protein synthesis, duodenal flows, and digestibility of amino acids (AA) in the intestines and the total tract. The experiment was a double $4 \times 4$ quasi-Latin square with a $2^{3}$ factorial arrangement of treatments. The dietary factors were extent of barley grain processing, coarse (processing in$\operatorname{dex}$; PI $=75.5 \%)$ or flat $(\mathrm{PI}=60.2 \%)$; forage-to-concentrate $(\mathrm{F}: \mathrm{C})$ ratio, low $(35: 65)$ or high $(55: 45)$ on a DM basis; and forage particle length (FPL), long $(7.59 \mathrm{~mm}$ ) or short $(6.08 \mathrm{~mm})$. Eight lactating cows with ruminal and duodenal cannulas were offered ad libitum access to a total mixed diet. There were no significant interactions between dietary treatments for ruminal $\mathrm{N}$ degradation or its duodenal flow and digestibility in the intestines. Passage of microbial protein to the duodenum was improved with increased F:C ratio of the diet but was not affected by grain processing or FPL. Ruminal digestibility of $\mathrm{N}$ was increased with increased $\mathrm{F}: \mathrm{C}$ ratio (49 vs. $60 \%$ ) and with reduced FPL (59 vs. 50\%). Increased grain processing improved $\mathrm{N}$ digestibility both in the intestine $(15 \%)$ and in the total tract (8\%). Reduction in the FPL of the diets reduced intestinal $\mathrm{N}$ digestion by $14 \%$ without affecting the $\mathrm{N}$ digestion in the total tract. Increased extent of grain processing tended to enhance duodenal flows of AA. In contrast, reducing FPL lowered flows of dietary AA to the duodenum because of lowered flows of feed plus endogenous N. Increased $\mathrm{F}: \mathrm{C}$ ratio of the diet did not change the flow of total AA, but there was a reduced flow of dietary AA and increased flow of microbial AA. Flows of several individual AA were increased by feeding flatly rolled barley with limited effects of F:C ratio or FPL. An interaction between grain processing and FPL was detected

Received February 11, 2003

Accepted March 15, 2004.

Corresponding author: K. A. Beauchemin; e-mail: beauchemin@ agr.gc.ca. for flows of some AA. Diets formulated with flatly rolled barley plus long FPL increased Arg, Thr, Asp, Glu, Ser, Tyr, and nonessential AA (NEAA) by more than $24 \%$, compared with other combinations of grain processing and FPL. Digestibility of essential AA (EAA) in the intestine $(68 \%)$ was higher than that of NEAA $(63 \%)$, but digestion of total AA (65\%) was similar to that of total N (66\%). Digestibilities of individual AA in the intestine ranged from 46 to $77 \%$ and were generally improved with increased grain processing. However, effects of F:C ratio or FPL on digestion of AA were limited. These results indicate that manipulation of dairy cow diets can improve ruminal $\mathrm{N}$ degradation, microbial protein synthesis, flows of AA to the duodenum, and intestinal digestibility of AA. Combining dietary factors can be more beneficial than changing individual dietary factors for improving the delivery of AA to the small intestine.

(Key words: grain processing, forage particle length, amino acid flow, dairy cow)

Abbreviation key: EAA = essential AA, F:C = forage to concentrate, $\mathbf{F P L}$ = forage particle length, NEAA = nonessential AA, $\mathbf{P I}=$ processing index.

\section{INTRODUCTION}

Protein requirements of dairy cows are met with microbial and RUP that escapes the rumen and is absorbed in the intestine. Clark et al. (1992), in reviewing the effects of 152 dietary treatments, indicated that microbial CP supplied an average of 59\% (range of 34 to $89 \%$ ) of the nonammonia $\mathrm{N}$ flow to the duodenum. However, the supply of AA that reaches the small intestine and is absorbed ultimately determines whether the protein requirement of the lactating dairy cow is met. Although protein requirements and supply are based on digestible total AA in the current NRC (2001) protein evaluation system for dairy cattle, the supply of an individual AA is likely also important for maximizing milk synthesis (Schwab et al., 1992). Information concerning the supply of AA derived from the diet and the rumen microbes for a range of feeds is limited, but is 
required for developing accurate protein evaluation systems.

Dietary changes can cause large fluctuations in the species composition of the ruminal microbial consortium (Cheng et al., 1977). A survey of literature revealed that in digestion trials the variations in intestinal AA profiles that determine quantity of individual AA available in the intestine are mainly caused by differences in the AA composition of dietary proteins and in the ratio between microbial protein and RUP (Rulquin and Vérité, 1993). Composition of the feed consumed and the quantity of microbial protein synthesized have a major influence on passage of AA to the duodenum (Overton et al., 1995).

Intestinal digestibility of individual AA is variable and affected by source and degradability of the dietary CP (Prange et al., 1984; Mabjeesh et al., 1996). In situ intestinal disappearance of essential AA (EAA) is lower than that of nonessential AA (NEAA) (van Straalen et al., 1997). Milk yield and milk protein content have increased in response to increased intake of CP or RUP in some studies (Cunningham et al., 1996) but not always (Mansfield and Stern, 1994). Such conflicting results could be due to variable absorption coefficients of individual AA for various protein sources. Information regarding digestibility of individual AA in the intestine is required for developing accurate protein evaluation systems for dairy cattle.

It is well documented that dietary factors that alter ruminal OM fermentability affect ruminal $\mathrm{N}$ metabolism and microbial protein synthesis (Clark et al., 1992; Dewhurst et al., 2000). For example, manipulating extent of grain processing alters duodenal microbial $\mathrm{N}$ flows in beef (Beauchemin et al., 2001) and dairy cattle (Yang et al., 2000). Changing forage-to-concentrate $(\mathbf{F}: \mathbf{C})$ ratio alters amount and rate of $\mathrm{OM}$ fermented in the rumen, and thus can vary microbial protein synthesis (Sniffen and Robinson, 1987). Adequate particle length of forage is necessary to maintain proper rumen function. Reduced forage particle length (FPL) can positively (Rode et al., 1985) or negatively (Yang et al., 2002) affect ruminal microbial protein synthesis, depending on how FPL influences the ruminal environment and digestion kinetics. However, information on how dietary factors affect duodenal AA flows and ruminal OM digestibility is limited (Firkins et al., 1986; van Vuuren et al., 1993). In addition, interactions among dietary factors, such as between F:C ratio and FPL, on microbial protein synthesis have been reported (Rode and Satter, 1988). A previous study showed interactions between grain processing and $\mathrm{F}: \mathrm{C}$ ratio on starch digestion (Yang et al., 2001b). The objectives of this study were to evaluate the effects of the extent of grain processing, F:C ratio, FPL, and their interactions on rumi- nal $\mathrm{N}$ metabolism, microbial protein synthesis, flows, and digestibility of individual AA in the intestine. Other aspects of this study were reported by Yang et al. (2001a, 2001b, 2001c).

\section{MATERIALS AND METHODS}

\section{Cows and Diets}

Eight lactating Holstein cows that were surgically fitted with ruminal and duodenal cannulas were used. The ruminal cannulas measured $10 \mathrm{~cm}$ in diameter and were constructed of soft plastic (Bar Diamond, Parma, ID). The open T-shaped duodenal cannulas were constructed of plastisol and were placed proximal to the common bile and pancreatic duct, approximately $10 \mathrm{~cm}$ distal to the pylorus. At the start of the experiment, the cows averaged $628 \pm 59 \mathrm{~kg}$ of BW and $134 \pm 35$ DIM. They were housed in individual tie stalls and milked twice daily in their stalls at 0700 and $1700 \mathrm{~h}$. Cows were offered a total mixed diet 3 times daily at 0630, 1500, and $1800 \mathrm{~h}$ for ad libitum intake. Cows were cared for according to the Canadian Council on Animal Care Guidelines (Ottawa, ON, Canada).

The experimental design was a double $4 \times 4$ quasiLatin square (Cochran and Cox, 1957) with a $2^{3}$ factorial arrangement of treatments and with four 21-d periods for each square. The design used in this experiment arranged half the treatments in square 1 and the other half in square 2 such that the 3 -way interactions were confounded, but all other effects were not confounded. Each period consisted of $11 \mathrm{~d}$ of adaptation to diets and $10 \mathrm{~d}$ of experimental measurements, including feed intake, ruminal $\mathrm{N}$ degradation, microbial protein synthesis, duodenal flows, and digestion in the intestine and the total digestive tract. Each period within square, cows received 1 of 4 diets, such that each cow received 4 of the 8 diets by completion of the study.

The 8 diets were formulated by combining 3 factors, each with 2 levels. The factors studied were grain processing (coarse vs. flat), F:C ratio (low vs. high), and FPL (long vs. short). Coarsely and flatly rolled barley was produced during the rolling process; F:C ratios were 35:65 and 55:45 for low and high, respectively, and long particle forage was the original forage regularly fed in the Dairy Unit at the Lethbridge Research Center, whereas the short particle forage was prepared by rechopping the alfalfa silage and barley silage and grinding the alfalfa hay through a 4-mm screen. Chemical composition differed between diets with low and high $\mathrm{F}: \mathrm{C}$ ratio. The low $\mathrm{F}: \mathrm{C}$ ratio diets consisted of approximately $10 \%$ alfalfa silage, $18 \%$ barley silage, $7 \%$ alfalfa hay, and $65 \%$ concentrate. High F:C ratio diets consisted of $16 \%$ alfalfa silage, $29 \%$ barley silage, $10 \%$ al- 
Table 1. Ingredients and chemical composition of the total mixed diets (DM basis).

\begin{tabular}{|c|c|c|}
\hline & \multicolumn{2}{|c|}{ Diets } \\
\hline & Low forage & High forage \\
\hline \multicolumn{3}{|l|}{ Ingredients } \\
\hline Alfalfa silage ${ }^{1,2}$ & 10.0 & 16.1 \\
\hline Barley silage $e^{1,2}$ & 17.8 & 28.5 \\
\hline Alfalfa hay ${ }^{1,2}$ & 7.2 & 10.4 \\
\hline Barley grain, steam-rolled ${ }^{2,3}$ & 50.2 & 27.6 \\
\hline Corn gluten meal & 2.92 & 3.32 \\
\hline Blood meal & 0.97 & 0.47 \\
\hline Canola meal & 4.39 & 1.42 \\
\hline Soybean meal & 0.97 & 4.75 \\
\hline Molasses, beet & 0.97 & 1.42 \\
\hline Calcium carbonate & 0.88 & 1.04 \\
\hline Dicalcium phosphorus & 0.44 & 0.52 \\
\hline Monophosphorus & 0.39 & 0.47 \\
\hline Vitamin-mineral mix ${ }^{4}$ & 0.38 & 2.58 \\
\hline Canola oil & 0.49 & 1.42 \\
\hline \multicolumn{3}{|l|}{ Chemical } \\
\hline $\mathrm{DM}$ & 64.8 & 57.1 \\
\hline $\mathrm{OM}$ & 91.1 & 89.5 \\
\hline $\mathrm{CP}$ & 17.9 & 18.3 \\
\hline NDF & 31.7 & 37.8 \\
\hline NDF from forages & 15.1 & 23.5 \\
\hline $\mathrm{ADF}$ & 17.4 & 23.9 \\
\hline Starch & 32.9 & 24.1 \\
\hline NEL, Mcal/kg 5 & 1.57 & 1.57 \\
\hline
\end{tabular}

${ }^{1}$ Chemical composition of alfalfa silage, barley silage, and alfalfa hay (DM basis) was 88.5, 91.8, and 90.7\% for OM; 41.7, 42.4, and $45.1 \%$ for NDF; $17.8,12.9$, and $17.7 \%$ for CP, respectively. Starch content of barley silage was $24.9 \%$.

${ }^{2}$ All ingredients except for forages and grain were pelleted.

${ }^{3}$ Physical characteristics of coarsely and flatly rolled barley were 75.5 and $60.2 \%$ for processing index; 1.60 and $1.36 \mathrm{~mm}$ for kernel thickness; 4.68 and $5.74 \mathrm{~mm}$ for kernel width, respectively.

${ }^{4}$ Contained 51.97\% NaCl, 35.98\% Dynamate (Pitman Moore, Inc., Mundelein, IL; $18 \% \mathrm{~K}, 11 \% \mathrm{Mg}, 22 \% \mathrm{~S}, 1000 \mathrm{mg} \mathrm{Fe} / \mathrm{kg}), 2 \%$ $\mathrm{ZnSO}_{4} \cdot \mathrm{H}_{2} \mathrm{O}, 2.4 \% \mathrm{MnSO}_{4} .4 \mathrm{H}_{2} \mathrm{O}, 0.01 \% \mathrm{CoSO}_{4} \cdot 6 \mathrm{H}_{2} \mathrm{O}, 0.009 \% \mathrm{Na}_{2}$ $\mathrm{SeO}_{3}, 0.012 \%$ ethylenediamine dihydroiodide, $0.8 \% \mathrm{CuSO}_{4} .5 \mathrm{H}_{2} \mathrm{O}$, $680,000 \mathrm{IU} / \mathrm{kg}$ of vitamin A, $160,000 \mathrm{IU} / \mathrm{kg}$ of vitamin $\mathrm{D}$, and 2,000 $\mathrm{IU} / \mathrm{kg}$ of vitamin $\mathrm{E}$.

${ }^{5}$ Estimated from NRC (2001).

falfa hay, and $45 \%$ concentrate (Table $1, \mathrm{DM}$ basis). The diets were formulated using the Cornell-Penn-Miner System (CPM Dairy, version 1.0) to supply adequate metabolizable energy and protein for a $600-\mathrm{kg}$ cow producing $30 \mathrm{~kg} / \mathrm{d}$ of milk with $3.5 \%$ fat and $3.2 \%$ protein.

Particle length of forages was determined using dry sieving technique as described previously (Yang et al., 2001b). Barley grain obtained from one source was used throughout the experiment. The barley was first screened to remove chaff and small kernels and then steam rolled to a coarse or fine thickness. Extent of rolling was quantified using a processing index (PI) measured as the volume weight of the barley after processing expressed as a percentage of its volume weight before processing (Yang et al., 2000).

Feed offered and orts were measured and recorded daily during the last $10 \mathrm{~d}$ of the period to calculate feed intake. Feed samples were collected once weekly, and orts were collected twice weekly for DM determination. Samples were ground through a 1-mm diameter screen (standard model 4, Arthur Thomas Co., Philadelphia, $\mathrm{PA}$ ) and composited by period for analysis of $\mathrm{CP}$ and AA.

\section{Duodenal Flow and Apparent Digestion}

Duodenal flow and apparent digestion of nutrients in the total tract were determined using $\mathrm{YbCl}_{3}$ (RhônePoulenc Inc., Shelton, CT). Ammonium sulfate enriched with ${ }^{15} \mathrm{~N}\left(\left[{ }^{15} \mathrm{NH}_{4}\right]_{2} \mathrm{SO}_{4}, 10.6 \%\right.$ atom $\%{ }^{15} \mathrm{~N}$; Isotec, Miamisburg, $\mathrm{OH}$ ) was used as a ruminal microbial marker. The marker solutions were continuously infused into the rumen via ruminal cannulas using an automatic pump (model $60 \mathrm{RPM} / 7524$ to 10 , Masterflex L/S Microprocessor pump drive; Cole-Parmer Instrument Co., Vernon Hills, IL) during the last 2 wk of the period. Daily amounts infused were $2.6 \mathrm{~g}$ of $\mathrm{Yb}$ and 180 $\mathrm{mg}$ of ${ }^{15} \mathrm{~N}$ dissolved in $850 \mathrm{~mL}$ of water for each cow. Ruminal, duodenal, and fecal samples were collected 4 times daily every $6 \mathrm{~h}$ moving ahead $2 \mathrm{~h}$ each day for the last $3 \mathrm{~d}$ of infusion. This schedule provided 12 representative samples of ruminal, duodenal, and fecal contents taken at 2-h intervals. Duodenal samples were pooled by cow for each period using a blender/mixer (model MX-9100, Toshiba, Tokyo, Japan) and freezedried for chemical analysis. Fecal samples were also pooled by cow for each period, dried at $55^{\circ} \mathrm{C}$, and ground through a 1-mm screen for chemical analysis. Isolation of ruminal bacterial pellets was outlined previously (Yang et al., 2001a).

\section{Chemical Analyses}

Feed DM was determined by oven drying at $55^{\circ} \mathrm{C}$ for $48 \mathrm{~h}$. Analytical DM content of the samples was determined by drying at $135^{\circ} \mathrm{C}$ for $3 \mathrm{~h}$ (AOAC, 1990). The OM content was calculated as the difference between DM and ash content, with ash content determined by combustion at $550^{\circ} \mathrm{C}$ overnight. The NDF and $\mathrm{ADF}$ contents were determined using the methods described by Van Soest et al. (1991) with amylase and sodium sulfite used in the NDF procedure. Contents of $\mathrm{Yb}$ in the samples were determined using atomic absorption spectrophotometry according to the AOAC (1990). Content of CP in the samples and enrichment of ${ }^{15} \mathrm{~N}$ in the bacteria isolated from the rumen and in duodenal digesta was determined by flash combustion (Carlo Erba Instruments, Milan, Italy) with isotope ratio mass spectrometry (VG Isotech, Middlewich, England). Amino acids in feed and digestive samples were analyzed as the phenylisothiocyanate derivatives by HPLC (WM02, Waters, Milford, MA) according to the 
Table 2. Intake of $\mathrm{N}$, microbial protein synthesis, duodenal flow, and digestibility of $\mathrm{N}$ as affected by grain processing $(\mathrm{G})$, forage:concentrate (F:C) ratio, or forage particle length $(\mathrm{P})$.

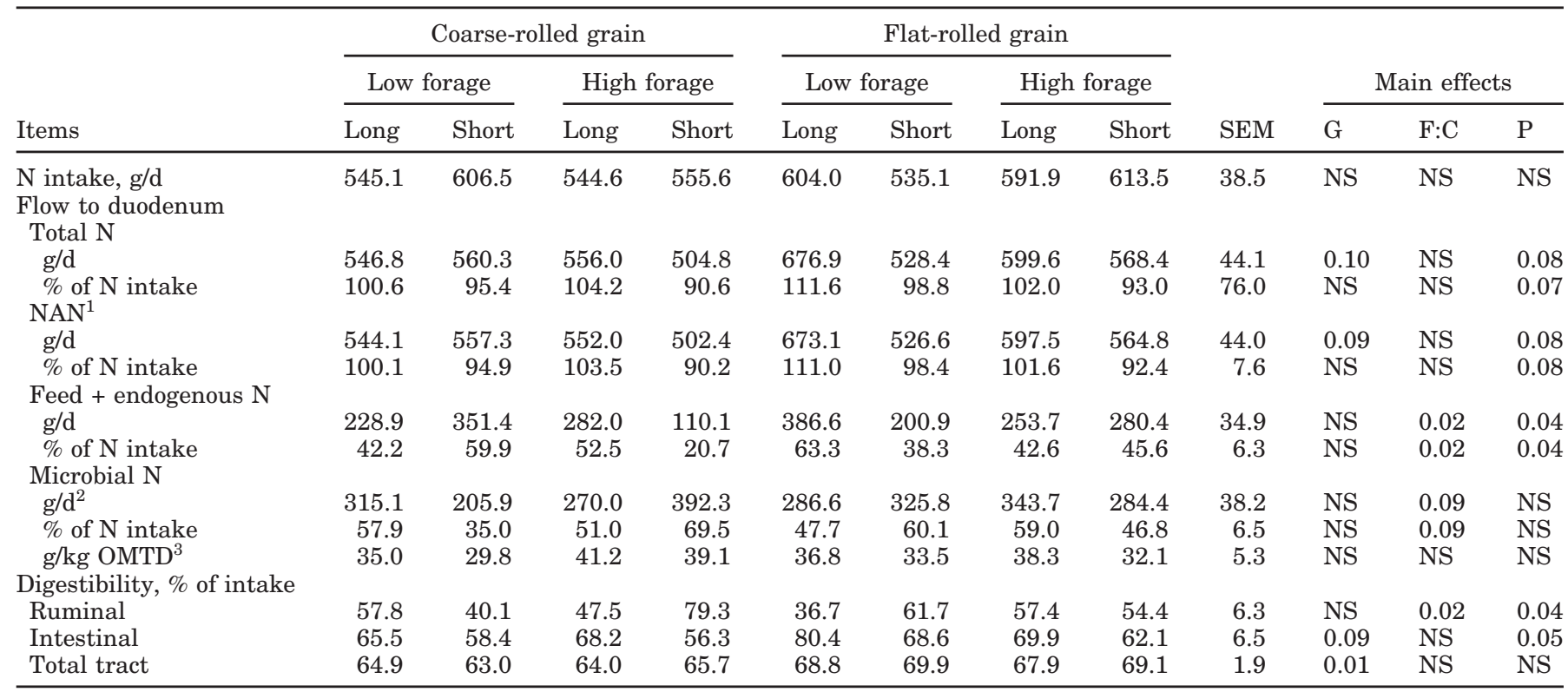

${ }^{1} \mathrm{NAN}=$ Nonammonia $\mathrm{N}$.

${ }^{2}$ Data from Yang et al. (2001a).

${ }^{3} \mathrm{OMTD}=\mathrm{OM}$ truly digested in the rumen.

$\mathrm{NS}=P>0.10$.

procedure of Hagen et al. (1989) with minor modifications in the oxidation step. A sample to contain $10 \mathrm{mg}$ of protein was oxidized with $5 \mathrm{~mL}$ performic acid. One milliliter of concentrated $\mathrm{HCl}$ and 3 drops of 1-octanol were added to allow samples to sit at room temperature before evaporation the next day. For derivatization, 40 $\mu \mathrm{L}$ of a derivatized $\mathrm{MeOH}$-water-triethylamine (2:2:1) solution was added into the derivatization tubes. The contents were dried by adding a phenylisothiocyanate mixture at room temperature and atmospheric pressure.

\section{Calculations and Statistical Analyses}

Flow of CP or AA to the duodenum was calculated by multiplying $\mathrm{CP}$ or AA concentration in duodenal DM by the flow of DM. The flow of DM was calculated by dividing the amount of $\mathrm{Yb}$ infused (grams of $\mathrm{Yb}$ per day) by $\mathrm{Yb}$ concentration (grams of $\mathrm{Yb}$ per kilogram of $\mathrm{DM})$ in the duodenal digesta. Similarly, the amount of $\mathrm{CP}$ or $\mathrm{AA}$ excreted in the feces was calculated by multiplying $\mathrm{CP}$ or AA concentration in fecal DM by the amount of DM excreted in feces. The amount of DM excreted was calculated by dividing $\mathrm{Yb}$ infused (grams of $\mathrm{Yb}$ per day) by $\mathrm{Yb}$ concentration (grams of $\mathrm{Yb}$ per kilogram of DM) in the feces. Ruminal microbial protein synthesis for each cow was estimated by the ratio of
${ }^{15} \mathrm{~N}$ flow at the duodenum to ${ }^{15} \mathrm{~N}$ concentration of ruminal bacteria.

For each period, means for individual cows were calculated for all variables. Data were analyzed using the mixed model procedure of SAS (Proc Mixed; SAS, 1996). The model included the fixed effects grain processing, F:C ratio, FPL, and their 2-way interactions. Threeway interactions were not included in the main effects because they were confounded due to the double $4 \times 4$ quasi-Latin square design. Square, period in square, and animal in square were considered as random effects. Effects of the factors were declared significant at $P<0.05$ unless otherwise noted, and trends were discussed at $P<0.10$.

\section{RESULTS}

\section{Intake, Duodenal Flow, and Intestinal Digestion of N}

Interactions of grain processing with $\mathrm{F}$ :C ratio or with FPL tended $(P<0.08)$ to be significant for intake of $\mathrm{N}$ (Table 2). When barley grain was coarsely rolled, increased F:C ratio reduced $\mathrm{N}$ intake (576 vs. $550 \mathrm{~g} /$ d), but when grain was flatly rolled, intake of $\mathrm{N}$ was increased with increasing F:C ratio (570 vs. $603 \mathrm{~g} / \mathrm{d}$ ). In contrast, reduced FPL increased $\mathrm{N}$ intake (545 vs. $581 \mathrm{~g} / \mathrm{d}$ ) when fed with coarsely rolled barley and de- 
Table 3. Intake of AA of dairy cows as affected by grain processing $(\mathrm{G})$, forage:concentrate $(\mathrm{F}: \mathrm{C})$ ratio, or forage particle length $(\mathrm{P})$.

\begin{tabular}{|c|c|c|c|c|c|c|c|c|c|c|c|c|}
\hline \multirow[b]{3}{*}{ Item } & \multicolumn{4}{|c|}{ Coarse-rolled grain } & \multicolumn{4}{|c|}{ Flat-rolled grain } & \multirow[b]{3}{*}{ SEM } & \multirow{2}{*}{\multicolumn{3}{|c|}{ Main effects }} \\
\hline & \multicolumn{2}{|c|}{ Low forage } & \multicolumn{2}{|c|}{ High forage } & \multicolumn{2}{|c|}{ Low forage } & \multicolumn{2}{|c|}{ High forage } & & & & \\
\hline & Long & Short & Long & Short & Long & Short & Long & Short & & $\mathrm{G}$ & $\mathrm{F}: \mathrm{C}$ & $\mathrm{P}$ \\
\hline \multicolumn{13}{|c|}{ Amino acid, $g / d$} \\
\hline Arg & 104.1 & 120.0 & 115.5 & 95.9 & 128.0 & 103.6 & 104.5 & 126.7 & 9.3 & $\mathrm{NS}$ & NS & NS \\
\hline His & 72.1 & 102.3 & 100.7 & 82.6 & 108.8 & 78.3 & 91.1 & 111.2 & 8.1 & NS & NS & NS \\
\hline Ile & 80.4 & 71.5 & 97.6 & 86.2 & 76.2 & 80.3 & 95.1 & 107.1 & 7.8 & NS & 0.01 & NS \\
\hline Met & 42.6 & 40.8 & 37.3 & 38.4 & 43.3 & 42.6 & 42.1 & 40.7 & 3.1 & NS & 0.07 & NS \\
\hline $\mathrm{Phe}^{\mathrm{a}}$ & 85.7 & 144.5 & 121.7 & 104.8 & 149.6 & 85.0 & 115.5 & 133.6 & 16.4 & NS & NS & NS \\
\hline Thr & 89.7 & 95.2 & 91.5 & 87.4 & 101.8 & 89.2 & 95.5 & 100.0 & 6.9 & 0.03 & NS & NS \\
\hline Val & 116.5 & 95.3 & 112.9 & 115.4 & 101.7 & 116.2 & 127.1 & 123.6 & 11.2 & NS & 0.08 & NS \\
\hline Ala & 139.3 & 144.7 & 174.5 & 147.0 & 154.5 & 138.9 & 161.7 & 192.2 & 14.0 & 0.10 & 0.01 & NS \\
\hline Asp & 162.0 & 140.8 & 161.3 & 167.8 & 152.2 & 162.0 & 185.0 & 175.5 & 14.3 & NS & 0.06 & NS \\
\hline Cys & 38.6 & 38.1 & 31.0 & 31.2 & 40.5 & 38.5 & 34.2 & 33.9 & 2.6 & 0.08 & 0.01 & NS \\
\hline Total AA & 2285.0 & 2370.0 & 2395.4 & 2231.4 & 2528.2 & 2276.1 & 2451.0 & 2620.1 & 146.9 & 0.01 & NS & NS \\
\hline $\mathrm{EAA}^{1}$ & 866.6 & 922.1 & 983.8 & 896.6 & 978.1 & 862.9 & 985.2 & 1077.9 & 57.7 & 0.01 & 0.01 & NS \\
\hline $\mathrm{NEAA}^{2}$ & 1418.4 & 1447.9 & 1411.6 & 1334.7 & 1550.0 & 1413.3 & 1465.9 & 1542.2 & 92.8 & 0.03 & NS & NS \\
\hline
\end{tabular}

${ }^{1}$ Essential AA = Arg, His, Ile, Leu, Lys, Met, Phe, Thr, and Val.

${ }^{2}$ Nonessential AA = Ala, Asp, Cys, Glu, Gly, Pro, Ser, and Tyr.

${ }^{\mathrm{a}} \mathrm{G} \times \mathrm{P}$ interaction $(P<0.05)$.

$\mathrm{NS}=P>0.10$.

creased $\mathrm{N}$ intake (598 vs. $574 \mathrm{~g} / \mathrm{d}$ ) when fed with flatly rolled barley.

There were few interactions between dietary treatments for duodenal $\mathrm{N}$ flow, microbial protein synthesis, and digestibility of $\mathrm{N}$, except for a tendency $(P<0.06)$ of interaction between grain processing and $\mathrm{F}: \mathrm{C}$ ratio for the duodenal flow of microbial $\mathrm{N}$ expressed as a percentage of $\mathrm{N}$ intake. When coarsely rolled barley was fed, increased $\mathrm{F}: \mathrm{C}$ ratio increased the proportion of microbial $\mathrm{N}$ derived from $\mathrm{N}$ intake from 46.4 to $60.2 \%$, but no change was observed when flatly rolled barley was fed (53.9 vs. $52.9 \%$ of $\mathrm{N}$ intake).

Increased extent of barley rolling tended to increase flows of total N $(P<0.10)$, NAN $(P<0.09)$, and feed N plus endogenous $\mathrm{N}(P<0.11)$ but did not affect passage of microbial protein to the duodenum or $\mathrm{N}$ degradability in the rumen. However, increased processing of grain improved $\mathrm{N}$ digestibility by $15 \%$ in the intestine $(P<$ 0.07 ) and by $8 \%$ in the total tract.

Increased $\mathrm{F}: \mathrm{C}$ ratio in the diet of dairy cows did not change duodenal flows of total $\mathrm{N}$ or NAN but increased $(P<0.09)$ microbial protein production by $14 \%$, and consequently reduced RUP by about $20 \%$. Changing the diet from low (35\%) to high forage (55\%) also significantly increased ruminal $\mathrm{N}$ degradability by $21 \%$ (from 49.1 to $59.6 \%$ of $\mathrm{N}$ intake). But digestibility of $\mathrm{N}$ in the intestine or in the total tract was not affected by the $\mathrm{F}: \mathrm{C}$ ratio.

Reduced FPL of the diet decreased RUP as well as flows of total N, and NAN tended $(P<0.08)$ to be decreased without affecting microbial protein synthesis (Table 2). Ruminal N digestion was higher with feeding short rather than long forage. An opposite result was observed for the intestinal $\mathrm{N}$ digestibility, and, consequently, digestibility of $\mathrm{N}$ in the total tract was similar for feeding either long or short forage.

\section{Intake of AA}

Intake of total AA was comprised of about $40 \% \mathrm{EAA}$ and 60\% NEAA (Table 3). Differences in AA intake (total, EAA, and NEAA) between cows fed coarsely and flatly rolled barley reflected the difference in DMI reported previously (Yang et al., 2001b). Furthermore, there was a trend for an interaction $(P<0.09)$ between grain processing and F:C ratio for intake of EAA because the magnitude of increased intake of EAA was greater with higher forage diets. Increased intake of EAA with high F:C ratio diets was due to the higher concentration of total EAA in the high vs. low forage diet. Forage particle length did not affect intake of AA.

There were interactions between grain processing and FPL for intakes of Ile $(P<0.07)$ and Phe (Table 3$)$. 
Table 4. Duodenal flow (g/d) of AA of dairy cows as affected by grain processing $(G)$, forage:concentrate (F:C) ratio, or forage particle length (P).

\begin{tabular}{|c|c|c|c|c|c|c|c|c|c|c|c|c|}
\hline \multirow[b]{3}{*}{ Item } & \multicolumn{4}{|c|}{ Coarse-rolled grain } & \multicolumn{4}{|c|}{ Flat-rolled grain } & \multirow[b]{3}{*}{ SEM } & \multirow{2}{*}{\multicolumn{3}{|c|}{ Main effects }} \\
\hline & \multicolumn{2}{|c|}{ Low forage } & \multicolumn{2}{|c|}{ High forage } & \multicolumn{2}{|c|}{ Low forage } & \multicolumn{2}{|c|}{ High forage } & & & & \\
\hline & Long & Short & Long & Short & Long & Short & Long & Short & & G & $\mathrm{F}: \mathrm{C}$ & $\mathrm{P}$ \\
\hline \multicolumn{13}{|l|}{ Amino acid } \\
\hline $\mathrm{Arg}^{\mathrm{b}}$ & 114.8 & 112.4 & 104.2 & 111.3 & 154.7 & 113.0 & 148.5 & 116.8 & 10.8 & 0.01 & NS & 0.02 \\
\hline His & 68.4 & 68.5 & 60.1 & 63.0 & 85.9 & 68.0 & 89.2 & 71.6 & 9.6 & 0.04 & NS & NS \\
\hline Ile & 72.3 & 63.8 & 68.8 & 87.7 & 92.0 & 83.5 & 88.0 & 75.3 & 13.6 & NS & NS & NS \\
\hline Met & 33.3 & 28.4 & 30.4 & 35.0 & 34.8 & 35.4 & 40.1 & 29.8 & 3.3 & NS & NS & NS \\
\hline Phe & 119.0 & 136.8 & 126.9 & 115.1 & 168.4 & 118.7 & 138.6 & 144.8 & 14.2 & 0.07 & NS & NS \\
\hline Thr & 110.1 & 101.3 & 106.7 & 110.9 & 146.3 & 106.8 & 133.9 & 114.7 & 10.8 & 0.03 & NS & 0.05 \\
\hline Val & 91.9 & 103.5 & 103.1 & 106.4 & 135.3 & 98.9 & 106.6 & 111.6 & 17.2 & NS & NS & NS \\
\hline Ala & 123.7 & 118.0 & 134.4 & 138.2 & 171.8 & 134.5 & 155.5 & 135.9 & 17.9 & 0.09 & NS & NS \\
\hline $\mathrm{Asp}^{\mathrm{a}}$ & 158.4 & 148.5 & 167.2 & 205.8 & 243.5 & 178.2 & 237.6 & 174.4 & 27.2 & 0.05 & NS & NS \\
\hline Cys & 37.8 & 34.7 & 35.0 & 32.2 & 38.5 & 36.3 & 39.8 & 32.6 & 3.4 & NS & NS & 0.09 \\
\hline Total AA & 2232.8 & 2316.2 & 2302.1 & 2315.8 & 3105.0 & 2269.4 & 2754.1 & 2436.0 & 271.0 & 0.08 & NS & NS \\
\hline $\mathrm{EAA}^{1}$ & 865.9 & 851.6 & 851.1 & 915.3 & 1154.8 & 912.0 & 1049.6 & 930.4 & 113.8 & 0.08 & NS & NS \\
\hline $\mathrm{NEAA}^{2}$ & 1366.9 & 1464.6 & 1451.0 & 1400.4 & 1950.2 & 1357.4 & 1704.6 & 1505.6 & 160.1 & 0.08 & NS & NS \\
\hline \multicolumn{13}{|l|}{ Bacterial } \\
\hline Total AA & 1336.5 & 961.9 & 1252.9 & 1937.3 & 1254.6 & 1533.5 & 1658.1 & 1337.5 & 200.2 & NS & 0.05 & NS \\
\hline $\mathrm{EAA}^{1}$ & 596.3 & 433.2 & 566.2 & 864.8 & 576.5 & 692.3 & 739.2 & 599.1 & 89.0 & NS & 0.05 & NS \\
\hline $\mathrm{NEAA}^{2}$ & 740.2 & 528.7 & 686.7 & 1072.6 & 678.2 & 841.1 & 918.9 & 738.3 & 111.5 & NS & 0.04 & NS \\
\hline
\end{tabular}

${ }^{1}$ Essential AA = Arg, His, Ile, Leu, Lys, Met, Phe, Thr, and Val.

${ }^{2}$ Nonessential AA = Ala, Asp, Cys, Glu, Gly, Pro, Ser, and Tyr.

${ }^{\mathrm{a}} \mathrm{G} \times \mathrm{P}$ interaction $(P<0.05)$

$\mathrm{NS}=P>0.10$.

When coarsely rolled barley was fed, increased FPL increased intake of Ile (79 vs. $89 \mathrm{~g} / \mathrm{d}$ ) but decreased intake of Phe (125 vs. $104 \mathrm{~g} / \mathrm{d}$ ), and the opposite differences were observed when flatly rolled barley was fed (Ile 94 vs. 86 g/d; Phe 109 vs. 133 g/d). Intakes of 6 out of 17 AA measured were higher (Thr and Ser) or tended $(P<0.10)$ to be higher (Leu, Ala, Cys, and Gly) when feeding coarsely, rather than flatly rolled barley. Intake of $10 \mathrm{AA}$ (Ile, Leu, Lys, Val, Ala, Asp, and Tyr increased; Met, Cys, Pro decreased) was affected by increasing $\mathrm{F}: \mathrm{C}$ ratio.

\section{Duodenal Flows of AA}

Flows of total AA, EAA, and NEAA to the duodenum, ranged from 2.2 to $3.1,0.85$ to 1.15 , and 1.36 to 1.95 $\mathrm{kg} / \mathrm{d}$, respectively, and were on average slightly greater than amounts consumed (Table 4). There was no interaction of $\mathrm{F}$ : $\mathrm{C}$ ratio with other dietary factors for duodenal flows of AA. However, an interaction (Arg and Asp) or a trend for an interaction $(P<0.10$; Glu, Ser, Tyr, and NEAA) was detected between grain processing and FPL for AA flow. These interactions were due to differ- ences in magnitude of response rather than direction. Therefore, the differences in duodenal AA flows were mainly due to the main effects. The flows of these AA were not affected by FPL when coarsely rolled barley was fed (long vs. short FPL, g/d, 110 vs. 112 for Arg, 108 vs. 106 for Thr, 163 vs. 177 for Asp, 414 vs. 443 for Glu, 136 vs. 136 for Ser, 101 vs. 97 for Tyr, and 1410 vs. 1430 for NEAA), but flows of these AA were higher with long FPL (152, 140, 241, 539, 179, 127, and 1830 g/d for Arg, Thr, Asp, Glu, Ser, Tyr, and NEAA, respectively) than with short FPL (115, 111, 176, 405, 141, 100, and $1430 \mathrm{~g} / \mathrm{d}$ for Arg, Thr, Asp, Glu, Ser, Tyr, and NEAA, respectively) when flatly rolled barley was fed.

Increased extent of barley rolling tended $(P<0.08)$ to increase flows of total AA, EAA, and NEAA to the duodenum, but the amounts increased were partitioned between bacterial and dietary AA, the portions of which were not affected by barley processing. Feeding high F:C ratio diets increased flows of bacterial total AA, EAA, and NEAA but lowered flows of dietary AA. Consequently, flows of total AA, EAA, and NEAA were not different between low and high $\mathrm{F}: \mathrm{C}$ ratio diets. Reduced FPL numerically $(P=0.15)$ decreased passage of total 
Table 5. AA profiles of duodenal protein of dairy cows as affected by grain processing $(\mathrm{G})$, forage:concentrate (F:C) ratio, or forage particle length $(\mathrm{P})$.

\begin{tabular}{|c|c|c|c|c|c|c|c|c|c|c|c|c|}
\hline \multirow[b]{3}{*}{ Item } & \multicolumn{4}{|c|}{ Coarse-rolled grain } & \multicolumn{4}{|c|}{ Flat-rolled grain } & \multirow[b]{3}{*}{ SEM } & \multirow{2}{*}{\multicolumn{3}{|c|}{ Main effects }} \\
\hline & \multicolumn{2}{|c|}{ Low forage } & \multicolumn{2}{|c|}{ High forage } & \multicolumn{2}{|c|}{ Low forage } & \multicolumn{2}{|c|}{ High forage } & & & & \\
\hline & Long & Short & Long & Short & Long & Short & Long & Short & & $\mathrm{G}$ & $\mathrm{F}: \mathrm{C}$ & $\mathrm{P}$ \\
\hline \multicolumn{13}{|c|}{ Individual AA, \% of AA-N } \\
\hline Arg & 5.14 & 4.85 & 4.56 & 4.85 & 5.17 & 5.03 & 5.41 & 4.81 & 0.31 & NS & NS & \\
\hline $\mathrm{His}^{\mathrm{a}}$ & 3.08 & 2.97 & 2.56 & 2.75 & 2.73 & 2.99 & 3.25 & 2.90 & 0.20 & NS & NS & NS \\
\hline Ile & 3.22 & 2.74 & 2.98 & 3.72 & 2.85 & 3.63 & 3.18 & 3.07 & 0.29 & NS & NS & NS \\
\hline $\mathrm{Leu}^{\mathrm{a}}$ & 6.19 & 5.40 & 5.87 & 6.99 & 5.48 & 6.81 & 6.06 & 5.63 & 0.48 & NS & NS & NS \\
\hline Lys & 5.24 & 4.82 & 5.00 & 5.21 & 5.01 & 5.68 & 4.98 & 5.23 & 0.24 & NS & NS & NS \\
\hline Met & 1.49 & 1.22 & 1.33 & 1.49 & 1.17 & 1.58 & 1.46 & 1.22 & 0.08 & NS & NS & NS \\
\hline $\mathrm{Phe}^{\mathrm{a}}$ & 5.33 & 5.99 & 5.52 & 4.99 & 5.47 & 5.23 & 5.03 & 5.91 & 0.20 & NS & NS & 0.06 \\
\hline Thr & 4.95 & 4.35 & 4.65 & 4.81 & 4.83 & 4.73 & 4.86 & 4.72 & 0.19 & NS & NS & 0.09 \\
\hline Val & 4.13 & 4.44 & 4.46 & 4.56 & 4.22 & 4.31 & 3.85 & 4.57 & 0.35 & NS & NS & NS \\
\hline $\mathrm{Ala}^{\mathrm{a}, \mathrm{b}}$ & 5.53 & 5.05 & 5.81 & 5.93 & 5.48 & 5.91 & 5.63 & 5.58 & 0.18 & NS & 0.02 & NS \\
\hline Asp & 7.07 & 6.26 & 7.17 & 8.89 & 7.78 & 7.66 & 8.62 & 7.24 & 0.51 & NS & 0.03 & NS \\
\hline $\mathrm{Cys}^{\mathrm{b}}$ & 1.70 & 1.50 & 1.53 & 1.39 & 1.29 & 1.60 & 1.44 & 1.33 & 0.09 & 0.05 & 0.07 & NS \\
\hline $\mathrm{Glu}^{\mathrm{b}}$ & 17.96 & 19.25 & 18.46 & 19.00 & 17.85 & 17.34 & 18.56 & 17.04 & 0.64 & 0.02 & NS & NS \\
\hline Gly & 6.76 & 6.77 & 6.75 & 6.19 & 7.12 & 6.80 & 6.75 & 7.18 & 0.39 & NS & NS & NS \\
\hline Pro & 11.84 & 14.04 & 12.83 & 9.41 & 13.02 & 11.05 & 10.31 & 12.65 & 0.82 & NS & 0.02 & NS \\
\hline Ser & 5.91 & 5.82 & 6.05 & 5.93 & 6.13 & 5.89 & 6.19 & 6.13 & 0.23 & NS & NS & NS \\
\hline $\mathrm{Tyr}^{\mathrm{a}}$ & 4.46 & 4.51 & 4.46 & 3.89 & 4.39 & 3.77 & 4.41 & 4.77 & 0.26 & NS & NS & NS \\
\hline $\mathrm{CP}, \%$ of $\mathrm{DM}$ & 24.1 & 22.6 & 22.8 & 23.3 & 24.6 & 24.5 & 23.6 & 23.2 & 1.14 & 0.06 & 0.08 & NS \\
\hline $\mathrm{AA}-\mathrm{N}, \% \mathrm{~N}$ & 64.3 & 64.8 & 65.6 & 72.1 & 70.5 & 66.8 & 72.1 & 67.8 & 3.26 & NS & NS & NS \\
\hline EAA-N, ${ }^{1} \%$ AA-N & 38.8 & 36.8 & 36.9 & 39.4 & 36.9 & 40.0 & 38.1 & 38.1 & 0.88 & NS & NS & NS \\
\hline
\end{tabular}

${ }^{1}$ Essential AA = Arg, His, Ile, Leu, Lys, Met, Phe, Thr, and Val.

${ }^{\mathrm{a}} \mathrm{G} \times \mathrm{F}: \mathrm{C}$ interaction $(P<0.05)$.

${ }^{\mathrm{b}} \mathrm{G} \times \mathrm{P}$ interaction $(P<0.05)$.

$\mathrm{NS}=P>0.10$.

AA and NEAA due to a significant reduction in flows of dietary AA without a change in flow of bacterial AA. There were 11 out of 17 AA that had higher duodenal flows for flatly rolled than coarsely rolled barley. However, feeding short FPL reduced flows of 7 AA, mostly for NEAA (Arg, Thr, Cys, Gly, Pro, Ser, and Tyr). Changing F:C ratio did not alter flows of individual AA except for Pro, which tended $(P<0.09)$ to be lower for high $\mathrm{F}: \mathrm{C}$ ratio than for low $\mathrm{F}: \mathrm{C}$ ratio diets.

\section{AA Profiles}

Interactions between grain processing and $\mathrm{F}: \mathrm{C}$ ratio were observed for profiles of His, Leu, Phe, Ala, and Tyr in duodenal contents, and between grain processing and FPL for Ala, Cys, and Glu, but no interaction of F:C ratio with FPL was observed (Table 5). When coarsely rolled barley was fed, proportions of AA in duodenal protein were decreased for His (3.02 to $2.66 \%$ ), Phe (5.66 to $5.25 \%$ ), and $\operatorname{Tyr}(4.49$ to $4.17 \%$ ) with increased $\mathrm{F}: \mathrm{C}$ ratio, but when flatly rolled barley was fed, proportions were increased for His (2.86 to $3.07 \%)$, Phe (5.35 to $5.47 \%$ ), and $\mathrm{Tyr}(4.08$ to $4.59 \%)$. In contrast, with increasing $\mathrm{F}$ :C ratio, proportions of Leu and Ala were increased. Proportions of Leu (5.80 to 6.43\%) and Ala (5.29 to $5.87 \%$ ) were increased with feeding coarsely rolled barley, and proportions of Leu were decreased (6.15 to $5.85 \%$ ) and unchanged for Ala (5.70 to 5.61\%) for feeding flatly rolled barley. In addition, when FPL was long and coarsely rolled barley was fed, proportions of Ala (5.49 to 5.67\%) and Cys (1.45 to 1.61\%) increased, and that of Glu (19.1 to 18.2\%) decreased. However, the opposite was observed when flatly rolled barley was fed: proportions of Ala (5.75 to 5.56\%), Cys (1.47 to $1.37 \%$ ), and Glu (17.2 to $18.2 \%$ ) increased. The proportion of Pro in duodenal protein was reduced from 12.5 to $11.3 \%$ by increasing the $\mathrm{F}: \mathrm{C}$ ratio, and no interaction was observed.

\section{Intestinal Digestion of AA}

Interactions between dietary treatments were seldom detected, and only interactions of grain processing with FPL were observed for intestinal digestibility of His $(P<0.10)$ and Cys (Table 6). Reducing FPL of the diets did not significantly change digestibility of His (long vs. short, 64.2 vs. $65.6 \%$ ) when coarsely rolled barley was fed, whereas the digestibility of His declined from 76.8 (long) to $69.7 \%$ (short) when finely rolled barley was fed. Furthermore, reduced FPL lowered the digestibility of Cys from 59.0 to $51.5 \%$ when coarsely 
Table 6. Intestinal digestibility (\% of intake) of AA in dairy cows as affected by grain processing $(\mathrm{G})$, forage:concentrate $(\mathrm{F}: \mathrm{C})$ ratio, or forage particle length $(\mathrm{P})$.

\begin{tabular}{|c|c|c|c|c|c|c|c|c|c|c|c|c|}
\hline \multirow[b]{3}{*}{ Item } & \multicolumn{4}{|c|}{ Coarse-rolled grain } & \multicolumn{4}{|c|}{ Flat-rolled grain } & \multirow[b]{3}{*}{ SEM } & \multirow{2}{*}{\multicolumn{3}{|c|}{ Main effects }} \\
\hline & \multicolumn{2}{|c|}{ Low forage } & \multicolumn{2}{|c|}{ High forage } & \multicolumn{2}{|c|}{ Low forage } & \multicolumn{2}{|c|}{ High forage } & & & & \\
\hline & Long & Short & Long & Short & Long & Short & Long & Short & & G & $\mathrm{F}: \mathrm{C}$ & $\mathrm{P}$ \\
\hline \multicolumn{13}{|c|}{ Amino acid } \\
\hline Arg & 69.2 & 68.3 & 70.2 & 67.1 & 78.8 & 76.4 & 74.8 & 73.0 & 3.3 & 0.01 & NS & NS \\
\hline His & 64.2 & 65.7 & 64.6 & 65.9 & 78.6 & 66.9 & 75.4 & 72.9 & 5.4 & 0.01 & NS & NS \\
\hline Ile & 68.7 & 64.7 & 66.3 & 72.8 & 72.3 & 74.5 & 74.8 & 68.8 & 5.2 & 0.10 & NS & NS \\
\hline Leu & 71.0 & 64.9 & 68.6 & 74.0 & 73.6 & 76.3 & 77.3 & 70.2 & 4.5 & 0.06 & NS & NS \\
\hline Lys & 70.4 & 71.6 & 70.1 & 69.6 & 75.9 & 76.6 & 74.5 & 74.9 & 3.4 & 0.03 & NS & NS \\
\hline Met & 55.9 & 51.8 & 50.6 & 48.6 & 53.0 & 67.8 & 54.5 & 50.7 & 5.5 & NS & NS & NS \\
\hline Phe & 65.8 & 68.1 & 68.8 & 64.1 & 77.2 & 68.9 & 69.9 & 74.2 & 3.0 & 0.01 & NS & NS \\
\hline Thr & 55.8 & 55.5 & 51.8 & 50.6 & 66.4 & 63.3 & 54.9 & 56.5 & 5.2 & 0.05 & 0.05 & NS \\
\hline Val & 54.5 & 56.4 & 56.2 & 58.5 & 62.3 & 61.4 & 58.8 & 60.0 & 7.2 & NS & NS & NS \\
\hline Ala & 53.9 & 50.7 & 53.1 & 55.9 & 61.8 & 62.0 & 59.1 & 54.4 & 5.2 & 0.09 & NS & NS \\
\hline Asp & 48.5 & 33.8 & 46.1 & 54.9 & 59.3 & 55.5 & 56.5 & 44.7 & 9.1 & NS & NS & NS \\
\hline $\mathrm{Cys}^{\mathrm{a}}$ & 59.8 & 58.3 & 58.7 & 45.1 & 58.1 & 68.0 & 50.7 & 55.5 & 5.9 & NS & 0.02 & NS \\
\hline Glu & 59.4 & 57.1 & 60.9 & 60.0 & 70.6 & 66.4 & 63.4 & 60.9 & 3.9 & 0.05 & NS & NS \\
\hline Gly & 65.5 & 67.2 & 66.3 & 59.2 & 75.5 & 71.7 & 69.0 & 68.6 & 3.2 & 0.01 & 0.07 & NS \\
\hline Pro & 68.7 & 71.1 & 76.4 & 65.3 & 81.3 & 74.6 & 74.8 & 78.7 & 2.4 & 0.01 & NS & 0.06 \\
\hline Ser & 53.4 & 53.0 & 51.5 & 48.4 & 64.1 & 61.3 & 55.2 & 54.2 & 4.6 & 0.03 & 0.08 & NS \\
\hline Tyr & 70.1 & 71.8 & 71.5 & 65.0 & 80.3 & 70.1 & 74.4 & 76.3 & 2.9 & 0.01 & NS & 0.07 \\
\hline Total AA & 62.7 & 63.8 & 64.6 & 60.5 & 66.5 & 69.6 & 62.4 & 68.0 & 2.9 & 0.06 & NS & NS \\
\hline $\mathrm{EAA}^{1}$ & 65.3 & 64.4 & 64.6 & 66.1 & 73.2 & 71.3 & 70.1 & 68.8 & 3.4 & 0.02 & NS & NS \\
\hline $\mathrm{NEAA}^{2}$ & 60.5 & 59.7 & 62.3 & 58.8 & 71.3 & 67.0 & 64.3 & 63.5 & 3.4 & 0.03 & NS & NS \\
\hline
\end{tabular}

${ }^{1}$ Essential AA = Arg, His, Ile, Leu, Lys, Met, Phe, Thr, and Val.

${ }^{2}$ Nonessential AA = Ala, Asp, Cys, Glu, Gly, Pro, Ser, and Tyr.

${ }^{\mathrm{a}} \mathrm{G} \times \mathrm{P}$ interaction $(P<0.05)$.

$\mathrm{NS}=P>0.10$.

rolled barley was fed, but digestibility of Cys increased from 54.1 to $61.5 \%$ when finely rolled barley was fed.

Digestibility of EAA was about $7 \%$ higher than that of NEAA regardless of dietary treatments, indicating that a preferential absorption of EAA occurred in the small intestine. Digestibilities of individual AA in the intestine were variable among AA and ranged from $46 \%$ for Asp to 77\% for Pro.

Increased grain processing improved intestinal digestibility of the majority of AA (13 out of 17 AA studied). As a result, digestibilities of total AA, EAA, and NEAA were increased by about $6(P<0.07), 9$, and $10 \%$, respectively. The digestibility of several AA was improved by reducing the F:C ratio (Thr, Cys, Gly, and Ser) or by feeding long $(P<0.07)$ FPL (Pro and Tyr).

\section{DISCUSSION}

\section{Ruminal N Metabolism}

Lack of effects of barley grain processing on microbial protein synthesis and $\mathrm{N}$ digestibility in the rumen are in agreement with other studies using dairy cows (Yang et al., 2000) or beef cattle (Beauchemin et al., 2001) fed barley-based diets. Although increased extent of barley processing improved ruminal starch digestion, ruminal $\mathrm{OM}$ digestion was unchanged due to decreased ruminal digestion of other nutrients (Yang et al., 2001b), suggesting that energy availability for ruminal microbial growth was similar for cows fed barley, with a PI ranging from 75 to $60 \%$.

Reduction in proportion of RUP in duodenal protein due to increased $\mathrm{F}: \mathrm{C}$ ratio resulted from a combination of a reduced flow of RUP and an increase in microbial $\mathrm{N}$ arriving at the duodenum. Higher microbial $\mathrm{N}$ flow with high F:C ratio diets agrees with Sniffen and Robinson (1987) who summarized the findings of several published studies, and suggested that maximum bacterial flow ( $\mathrm{g}$ of N/kg of apparent digested OM) is achieved at about $70 \%$ forage in diet. In contrast, Rode et al. (1985) reported that flow of bacterial $\mathrm{N}$ to the duodenum was maximized when the diet contained only $38 \%$ alfalfa hay rather than 58 or $80 \%$ hay. However, in that study when a correction was made for the amount of $\mathrm{DM}$ consumed, flow of microbial $\mathrm{N}$ to the duodenum per unit of $\mathrm{OM}$ truly digested in the rumen (i.e., microbial efficiency) was greatest for cows fed diets containing $80 \%$ hay. In the present study, microbial efficiency was numerically improved $(P=0.15)$ by $12 \%$ with increasing $\mathrm{F}: \mathrm{C}$ ratio. Effects observed due to $\mathrm{F}: \mathrm{C}$ ratio may be related to the amount of OM fermented in the rumen, rate of passage out of the rumen (Rode et al., 1985), and/or microbial colonization of feed particles (Yang et 
al., 2001a). Higher microbial protein yield associated with high F:C ratio diets was likely due to increased bacterial attachment and greater ruminal pool size of solid attached bacteria because ruminal OM digestion and passage rate did not differ (Yang et al., 2001b, 2001c).

The decrease in dietary $\mathrm{N}$ flow to the duodenum with reduced FPL was likely due to higher $\mathrm{N}$ degradation in the rumen. Feeding short FPL rather than long FPL to dairy cows might have increased the rate of degradation of the protein in the forage and thus, increased its content of RDP and, as a result, reduced its content of RUP. The present results are in agreement with Firkins et al. (1986) who reported that feeding ground hay resulted in lower flow of dietary $\mathrm{N}$ to the duodenum, compared with feeding chopped hay due to improved OM digestion. In the present study, ruminal digestion of OM was numerically higher for short (51\%) than for long (46\%) forage diets (Yang et al., 2001b).

Increased ruminal digestibility of $\mathrm{N}$ by increasing F:C ratio or by reducing FPL was apparently due to highly degradable forage $\mathrm{N}$. The highest microbial protein synthesis was observed when diets were formulated with coarsely rolled barley plus high $\mathrm{F}: \mathrm{C}$ ratio or short FPL plus high F:C ratio, when microbial protein synthesis was expressed as grams per day or percentage of $\mathrm{N}$ intake, indicating that feeding high-forage diets was beneficial to microbial protein production under the conditions of this experiment. Because the diets used were formulated to meet the energy requirements of the cows, microbial $\mathrm{N}$ production was likely influenced more by ruminal $\mathrm{pH}$ and passage rate of rumen contents than nutrient availability. Mean ruminal $\mathrm{pH}$ of cows fed diets containing coarsely rolled barley plus high F:C ratio was 6.14 (compared with 5.98 , average of others), and passage rate of ruminal solids of cows fed diets containing short-forage particle plus high F:C ratio was $4.72 \% / \mathrm{h}$ (compared with $3.85 \% / \mathrm{h}$, average of others).

\section{Intake and Duodenal Flows of AA}

Effects of grain processing and FPL on intake of AA reflected changes in DMI because AA contents of the diets (coarse vs. flat and long vs. short) were identical. Thus, higher intake of AA for cows fed more extensively processed grain was due to higher DMI. In contrast, feeding higher forage diets increased the intake of several individual EAA and, consequently, increased intake of total EAA due to the higher AA content of the diet rather than differences in DMI. Contents $(\%$ of total AA) of EAA are marginally higher in alfalfa hay (44.1\%) (Prange et al., 1984) and in alfalfa silage
(45.2\%) (Cunningham et al., 1993) than in barley grain (42.3\%) (Prestlokken, 1999).

The trend toward increased duodenal flows of total AA, EAA, or NEAA with increasing extent of barley processing appeared to be mainly due to more dietary AA arriving at the duodenum rather than increased microbial AA flow. In fact, the increased extent of barley processing increased DMI (coarse vs. flat, 19.5 vs. 20.7 $\mathrm{kg} / \mathrm{d}$ ) and ruminal starch digestion but had negative effects on fiber and $\mathrm{N}$ digestion (Yang et al., 2001b). Overton et al. (1995) showed that DMI and microbial protein synthesis have a major influence on passage of AA to the duodenum. Those workers reported that cows fed a corn-based diet relative to a barley-based diet, or a mixed barley and corn-based diet, had the greatest passage of AA to the duodenum because of greater DMI. Increased duodenal flow of most individual AA by increased extent of grain processing was expected because of the increase in DMI resulting from feeding further processed barley.

Increased $(P<0.09)$ passage of microbial protein to the duodenum with high $\mathrm{F}: \mathrm{C}$ ratio diets $(39 \mathrm{~g} / \mathrm{d})$ did not improve the flow of AA to the duodenum because of an offsetting decrease in flow of dietary $\mathrm{N}(60 \mathrm{~g} / \mathrm{d})$. The present finding is in agreement with Clark et al. (1992) who reviewed a number of digestion trials in which diets containing from 24 to $81 \%$ forage were used, and concluded that altering $\mathrm{F}: \mathrm{C}$ ratio in the diet within the range required for maximum milk production does not greatly affect the quantity or pattern of AA that pass to the duodenum. Thus, simply altering the $\mathrm{F}: \mathrm{C}$ ratio probably does not enhance the passage of AA to the duodenum. Other factors that may influence passage of AA to the duodenum include adequacy of fermentable carbohydrate, effective fiber, and supply of RDP. However, failure to detect any interaction of $\mathrm{F}: \mathrm{C}$ ratio with grain processing or with FPL for passage of AA to the duodenum in the present study may indicate that dairy cows are largely adapted to variable feeding conditions, or an optimum combination of dietary factors was not used.

The numerical reduction in the flows of total AA due to feeding short FPL was the result of a lower flow of dietary AA to the duodenum rather than a change in the flow of microbial N. Nevertheless, feeding long FPL was beneficial for flows of Arg, Thr, and several other NEAA. These results are in agreement with Firkins et al. (1986) who reported no differences in bacterial flow or total duodenal flows of EAA, NEAA, or total AA due to particle length of hay in the diet. Higher flows of total AA $(P<0.15)$ or several individual AA $(P<0.10)$ obtained by feeding diets containing flatly rolled barley plus long FPL were apparently due to a higher percent- 
age of AA-N in the total $\mathrm{N}$ of duodenal digesta or higher profiles of those AA.

\section{AA Profiles of Duodenal Protein}

In the present study, because AA profiles of ruminal bacteria were little affected by dietary treatments (Yang et al., 2001a), the differences in AA profiles in duodenal protein were due to variation of AA profiles of dietary protein and the ratio of microbial protein to RUP. Interactions of grain processing with $\mathrm{F}$ : C ratio or with FPL for profiles of AA in duodenal protein were in agreement with interactions of grain processing with $\mathrm{F}: \mathrm{C}$ ratio or with FPL for intake of $\mathrm{N}$ and proportion of microbial $\mathrm{N}$ flow in $\mathrm{N}$ intake. Increased proportion of microbial $\mathrm{N}$ would reduce the proportions of His, Phe, and Tyr but increase that of Ala and Leu because rumen bacteria have lower His, Phe, and Tyr and higher Ala and Leu (Yang et al., 2001a) compared with dietary AA profiles. The present results confirm findings of the extensive survey of literature by Rulquin and Vérité (1993) that variations in intestinal AA profiles are mainly caused by differences in the AA composition of dietary proteins and in the ratio between microbial protein and RUP. Although AA profiles of duodenal protein were affected by the dietary treatments studied, these differences in AA profiles had minimal effects of biological significance on duodenal AA flows.

\section{Intestinal Digestion of $\mathbf{N}$ and AA}

Because there was no interaction between dietary factors, differences in digestibilities of $\mathrm{N}$ were due to main effects. Increased digestibility of $\mathrm{N}$ both in the intestine and in the total tract with increasing extent of rolled barley was in agreement with previous findings (Yang et al., 2000; Beauchemin et al., 2001). Based on the results of a previous study (Yang et al., 2000), increased grain processing was expected to increase $\mathrm{N}$ digestibility because of more microbial $\mathrm{N}$ reaching the intestine. Microbial $\mathrm{N}$ digestibility in the intestine is high (78\%) (Hvelplund, 1985). However, ruminal microbial protein synthesis was not affected by grain processing in the present study. Thus, improved $\mathrm{N}$ digestibility must have resulted from a change in the contribution of microbial protein in the large intestine. Low ruminal starch digestion in cows fed coarsely rolled barley (Yang et al., 2001b) could have resulted in more starch available for bacterial fermentation in the large intestine, and consequently increased bacterial $\mathrm{N}$ excretions. About $80 \%$ of fecal $\mathrm{N}$ can be ascribed to bacterial and endogenous $\mathrm{N}$ of which about $80 \%$ is of microbial origin (Mason, 1979).

Digestibilities were similar between total N (66\%) and $\mathrm{AA}(65 \%)$, and these estimates were in agreement with Mabjeesh et al. (1996) but not with others (Santos et al., 1984; Stern et al., 1985) who reported that intestinal digestibility of AA was about 4 percentage units higher than that of total N. Higher digestibility of AA is apparently expected because digestibility of bacterial $\mathrm{N}$ is typically lower (range of 70 to $82 \%$, with an average of $78 \%$ ) than that of AA (range of 82 to $91 \%$, with an average of 85\%) (Hvelplund, 1985). In addition, Hvelplund (1985) also pointed out that the greatest difference in digestibility of $\mathrm{N}$ and $\mathrm{AA}$ was found in feeds with the lowest $\mathrm{N}$ digestibility because of a higher proportion of cell wall bound N compared with AA. Microbial protein synthesis and cell wall digestion in the total tract (Yang et al., 2001b) were not significantly affected by the treatments. The present results confirm that intestinal $\mathrm{N}$ digestibility is a good predictor of total AA digestibility, as concluded by Weisbjerg et al. (1996).

Higher digestibility of EAA than that of NEAA, regardless of dietary treatments, supports the observations of Santos et al. (1984) that the ratio of EAA:NEAA decreased from 0.79 in the duodenal digesta to 0.73 in the ilea digesta, indicating that a preferential absorption of EAA occurred in the small intestine. A slightly higher in situ intestinal digestibility of ruminal undegradable EAA vs. NEAA was also observed by van Straalen et al. (1997) for 7 out of 9 feeds studied.

The increased intestinal AA digestibility achieved by increasing grain processing was consistent with increased digestion of other nutrients, including OM, starch (Yang et al., 2001b), and N. Increased grain processing in the diets of dairy cows likely improved digestion of the grain, but had no effect on digestion of the forage (Yang et al., 2001b). Reducing the F:C ratio in dairy cow diets is apparently favorable for the intestinal digestion of Thr, Cys, Gly, or Ser. Ben-Ghedalia and Solomon (1988) reported that when the proportion of wheat straw in the diets was decreased from 100 to 70 , and then 30 to $0 \%$, the proportion of overall digestibility accounted for by individual AA digestibility linearly increased from 86 to $94 \%$ for Thr, from 88 to $99 \%$ for Ser, and from 92 to $99 \%$ for Gly. A lower disappearance of Cys in situ in the intestine was also detected by van Straalen et al. (1997) for grass silage (Cys vs. average, 78 vs. $89 \%$ ) and corn silage (53 vs. $67 \%$ ) but not for concentrate ( $88 \mathrm{vs.} .90 \%$ ). Increased microbial fermentation in the large intestine, as was the case for cows fed coarsely rolled barley grain or low $\mathrm{F}$ :C ratio diets, would increase AA excretion in the feces, and thus reduce apparent AA digestibility in the intestine.

The improvement in His digestibility due to feeding flatly rolled barley with long FPL was notable, but the reason for this improvement is not clear. It is possible that because barley grain contains more His (30\%) than other EAA (18 to $22 \%$ ) relative to alfalfa forage (NRC, 
Table 7. Measured versus predicted duodenal flows of essential AA (EAA) using various models ${ }^{1}$ for dairy cows fed low or high forage diets.

\begin{tabular}{|c|c|c|c|c|c|c|c|c|}
\hline \multirow[b]{3}{*}{ Item } & \multicolumn{8}{|c|}{ Diets } \\
\hline & \multicolumn{4}{|c|}{ Low forage $-35 \%$} & \multicolumn{4}{|c|}{ High forage $-55 \%$} \\
\hline & Measured & NRC & CPM Dairy & CNCPS & Measured & NRC & CPM Dairy & CNCPS \\
\hline \multicolumn{9}{|c|}{ Duodenal flow of EAA, $\mathrm{g} / \mathrm{d}$} \\
\hline Arg & 124 & 115 & 170 & 167 & 120 & 114 & 163 & 150 \\
\hline His & 73 & 59 & 79 & 77 & 71 & 55 & 74 & 67 \\
\hline Ile & 78 & 122 & 152 & 145 & 80 & 123 & 148 & 133 \\
\hline Met & 33 & 50 & 65 & 63 & 34 & 49 & 62 & 56 \\
\hline Phe & 136 & 134 & 162 & 156 & 131 & 133 & 155 & 140 \\
\hline Thr & 116 & 125 & 138 & 136 & 117 & 122 & 132 & 122 \\
\hline Val & 107 & 148 & 177 & 176 & 107 & 144 & 170 & 160 \\
\hline Total EAA & 946 & 1166 & 1383 & 1345 & 937 & 1145 & 1330 & 1211 \\
\hline
\end{tabular}

${ }^{1} \mathrm{NRC}=$ National Research Council. 2001 Nutrient Requirements of Dairy Cattle; CPM Dairy = Cornell-Penn-Miner System, version 2.023; CNCPS = Cornell Net Carbohydrate and Protein System, version 5.0.

2001), and because increased grain processing improved mainly the digestion of the barley portion, more His was digested. In addition, intestinal digestion of $\mathrm{N}$ was higher with long than with short FPL diets.

\section{Modeling Requirements of AA}

Requirements for individual AA by lactating cows are yet to be established. Current recommendations for Lys and Met, AA that can limit milk yield, should be 14.9 and $3.9 \%$ of EAA, respectively, in duodenal protein based on the in vivo measurements of Schwab et al. (1992), be 16.2 and $5.55 \%$, respectively for NRC (2001), or be 16.8 and $5.3 \%$, respectively according to CPMDairy (version 2.023). In the present study, proportions of Lys (\% of EAA flow) in the duodenal protein ranged from 13.4 to 13.7, and that of Met (\% of EAA flow) varied from 3.5 and 3.7. Therefore, the differences between proportions of Lys in the diets were negligible. Based on the findings of Schwab et al. (1992), both Lys and Met were marginally deficient in the diets used in the present study. However, in comparison with other models (NRC, 2001; CPM-Dairy, version 2.023; CNCPS), there was an $18 \%$ deficiency of Lys and a $33 \%$ deficiency of Met.

Similarly, the duodenal flows of EAA measured in the present study were also significantly lower than those estimated from the models, regardless of the forage levels in the diets (Table 7). Measured duodenal flows of EAA were about 18\% lower than NRC (2001) estimates, with 5 of 9 EAA less than model predictions. Furthermore, measured duodenal flows of EAA were about 29\% lower than predicted using the other 2 models. These results indicate that a difference in estimates of AA supply exists not only between in vivo measurements and prediction models, but also among the mod- els. Estimates of EAA supply using NRC (2001) were, on average, about 15 and 10\% lower for low- and highforage diets, respectively, than estimates using CPMDairy or CNCPS. Those 2 models gave similar estimates for low F:C ratio diets but different estimates when a high $\mathrm{F}$ : $\mathrm{C}$ ratio diet was fed. The relatively low proportion of $\mathrm{AA}$ in total duodenal $\mathrm{N}(68 \%)$ obtained in the present study versus the values used in the models (80\%) could partially explain the lower duodenal AA flows from the present study. This discrepancy may bring into question the accuracy of AA analysis used in this study. However, the AA analyses were validated with standard samples of known AA composition.

\section{CONCLUSIONS}

Manipulation of dietary factors significantly changed ruminal $\mathrm{N}$ metabolism and flows of AA to the duodenum. Increasing the extent of grain processing improved duodenal flows of nonammonia $\mathrm{N}$, total $\mathrm{AA}$, and most individual AA due to increased DMI. Increasing the proportion of forage in the diet enhanced ruminal microbial protein synthesis and increased ruminal $\mathrm{N}$ degradation but had minor effects on flows of AA to the duodenum. Reduction of FPL decreased passage of $\mathrm{N}$ and $\mathrm{AA}$ to the duodenum due to an apparent increased loss of ammonia from the rumen. There was an important interaction between grain processing and FPL for duodenal AA flows. The diet containing flatly rolled barley and long forage particles supplied $24 \%$ more AA to the duodenum, compared with other combinations of grain processing and FPL. Duodenal flows of AA were about 18 or $29 \%$ lower than predicted using NRC or CPM-Dairy models, respectively.

In addition, increasing the extent of barley processing improved intestinal digestibilities of $\mathrm{N}$ and $\mathrm{AA}$, espe- 
cially for several EAA, such as Arg, His, Met, and Thr, for which digestibility and absorption increased by more than 10 and $30 \%$, respectively. However, manipulation of forage proportion or FPL of the diet had limited effects on $\mathrm{N}$ and AA digestibility even though reduced F:C ratio of the diet improved digestion of Thr, Cys, Gly, and Ser.

These results emphasize the importance of conducting studies to evaluate multiple dietary factors rather than a single dietary factor. A change in the ratio of microbial protein to dietary protein in duodenal digesta due to dietary treatments is not necessary to alter flows of total or individual AA because of feedstuff differences in the AA profile of ruminal escape protein. Digestibility of total $\mathrm{N}$ in the intestine is a good indicator of total AA digestibility.

\section{ACKNOWLEDGMENTS}

This experiment was financially supported by the Alberta Dairy Producers (Edmonton, AB) and the Canada/Alberta Livestock Research Trust (Lethbridge, AB). The authors thank K. Andrews, G. Bowman, B. Farr, D. Vedres, and R. Wuerfel for their assistance in performing laboratory analyses and the staff of the Lethbridge Research Centre dairy unit for care of the cows.

\section{REFERENCES}

Association of Official Analytical Chemists. 1990. Official Methods of Analysis. Vol. I. 15th ed. AOAC, Arlington, VA.

Beauchemin, K. A., W. Z. Yang, and L. M. Rode. 2001. Effects of barley grain processing on the site and extent of digestion in beef cattle. J. Anim. Sci. 79:1925-1936.

Ben-Ghedalia, D., and R. Solomon. 1988. Amino acids flow to and absorption from the small intestine of sheep fed barley and sulfur dioxide-treated straw at different ratios. Anim. Feed Sci. Technol. 22:147-159.

Cheng, K.-J., D. E. Akin, and J. W. Costerton. 1977. Rumen bacteria: Interaction with particulate dietary components and response to dietary variations. Fed. Proc. 36:193-197.

Clark, J. H., T. H. Klusmeyer, and M. R. Cameron. 1992. Microbial protein synthesis and flows of nitrogen fractions to the duodenum of dairy cows. J. Dairy Sci. 75:2304-2323.

Cochran, W. G., and G. M. Cox. 1957. Page 611 in Experimental Designs, 2nd ed., John Wiley \& Sons, Inc. New York, NY.

Cunningham, K. D., M. J. Cecava, and T. R. Johnson. 1993. Nutrient digestion, nitrogen, and amino acid flows in lactating cows fed soybean hulls in place of forage or concentrate. J. Dairy Sci. 76:3523-3535.

Cunningham, K. D., M. J. Cecava, T. R. Johnson, and P. A. Ludden. 1996. Influence of source and amount of dietary protein on milk yield by cows in early lactation. J. Dairy Sci. 79:620-630.

Dewhurst, R. J., D. R. Davies, and R. J. Merry. 2000. Microbial protein supply from the rumen. Anim. Feed Sci. Technol. 85:1-21.

Firkins, J. L., L. L. Berger, N. R. Merchen, and G. C. Fahey, Jr. 1986. Effects of forage particle size, level of feed intake and supplemental protein degradability on microbial protein synthesis and site of nutrient digestion in steers. J. Anim. Sci. 62:1081-1094.

Hagen, S. R., B. Frost, and J. Augustin. 1989. Precolumn phenylisothiocyanate derivatization and liquid chromatograph of amino acids in food. J. Assoc. Off. Anal. Chem. 72:912-916.
Hvelplund, T. 1985. Digestibility of rumen microbial protein and undegraded dietary protein estimated in the small intestine of sheep and by in sacco procedure. Acta Agric. Scand. Suppl. 25:132-144.

Mabjeesh, S. J., A. Arieli, I. Bruckental, S. Zamwell, and H. Tagari. 1996. Effect of type of protein supplementation on duodenal amino acids flow and absorption in lactating dairy cows. J. Dairy Sci. 79:1792-1801.

Mansfield, H. R., and M. D. Stern. 1994. Effects of soybean hulls and lignosulfonate-treated soybean meal on ruminal fermentation in lactating dairy cows. J. Dairy Sci. 77:1070-1083.

Mason, V. C. 1979. The quantitative importance of bacterial residues in the non-dietary faecal nitrogen of sheep. 2. Estimates of bacterial nitrogen in faecal material from 47 digestibility trials. $Z$. Tierphysiol. Tierernahrg. U. Futtermittelkde. 41:140-149.

National Research Council. 2001. Nutrient Requirements of Dairy Cattle. 7th rev. ed. Natl. Acad. Sci., Washington, DC.

Overton, T. R., M. R. Cameron, J. P. Elliott, J. H. Clark, and D. R. Nelson. 1995. Ruminal fermentation and passage of nutrients to the duodenum of lactating cows fed mixtures of corn and barley. J. Dairy Sci. 78:1981-1998.

Prange, R. W., M. D. Stern, N. A. Jorgensen, and L. D. Satter. 1984. Site and extent of protein digestion in lactating cows fed alfalfa silage or baled alfalfa hay. J. Dairy Sci. 67:2308-2314.

Prestlokken, E. 1999. Ruminal degradability and intestinal digestibility of protein and amino acids in barley and oats expander-treated at various intensities. Anim. Feed Sci. Technol. 82:157-175.

Rode, L. M., D. C. Weakley, and L. D. Satter. 1985. Effect of forage amount and particle size in diets of lactating dairy cows on site of digestion and microbial protein synthesis. Can. J. Anim. Sci. 65:101-111.

Rode, L. M., and L. D. Satter. 1988. Effect of amount and length of alfalfa hay in diets containing barley or corn on site of digestion and rumen microbial protein synthesis in dairy cows. Can. J. Anim. Sci. 68:445-454.

Rulquin, H., and R. Vérité. 1993. Amino acid nutrition of dairy cows: Production effects and animal requirements. Pages 55-77 in Recent Advances in Animal Nutrition. P. C. Garnsworthy and D. J. A. Cole, ed. Nottingham University Press, UK.

SAS Inst. Inc. 1996. SAS User's Guide: Statistics, Version 7 Edition. SAS Inst., Inc., Cary, NC.

Santos, K. A., M. D. Stern, and L. D. Satter. 1984. Protein degradation in the rumen and amino acid absorption in the small intestine of lactating dairy cattle fed various protein sources. J. Anim. Sci. 58:244-255.

Schwab, C. G., C. K. Bozak, N. L. Whitehouse, and M. M. A. Meshah. 1992. Amino acid limitation and flow to duodenum at four stages of lactation. 1. Sequence of lysine and mehionine limitation. J. Dairy Sci. 75:3486-3502.

Sniffen, C. J., and P. H. Robinson. 1987. Microbial growth and flow as influenced by dietary manipulations. J. Dairy Sci. 70:425-441.

Stern, M. D., K. A. Santos, and L. D. Satter. 1985. Protein degradation in rumen and amino acid absorption in small intestine of lactating dairy cattle fed heat-treated whole soybeans. J. Dairy Sci. 68:45-56.

Van Soest, P. J., J. B. Robertson, and B. A. Lewis. 1991. Methods for dietary fiber, neutral detergent fiber and non-starch polysaccharide in relation to animal nutrition. J. Dairy Sci. 74:35833597.

Van Straalen, W. M., J. J. Odinga, and W. Mostert. 1997. Digestion of feed amino acids in the rumen and small intestine of dairy cows measured with nylon-bag techniques. Br. J. Nutr. 77:83-97.

Van Vuuren, A. M., C. J. van der Koelen, and J. vroons de Bruin. 1993. Ryegrass versus corn starch or beet pulp fiber diet effects on digestion and intestinal amino acids in dairy cows. J. Dairy Sci. 76:2692-2700.

Weisbjerg, M. R., T. Hvelplund, S. Hellberg, S. Ilsson, and S. Sanne. 1996. Effective rumen degradability and intestinal digestibility of individual amino acids in different concentrates determined in situ. Anim. Feed Sci. Technol. 62:179-188. 
Yang, W. Z., K. A. Beauchemin, and L. M. Rode. 2000. Effects of barley grain processing on extent of digestion and milk production of lactating cows. J. Dairy Sci. 83:554-568.

Yang, W. Z., K. A. Beauchemin, and L. M. Rode. 2001a. Effect of dietary factors on distribution and chemical composition of liquidor solid-associated bacterial population in the rumen of dairy cows. J. Anim. Sci. 79:2736-2746.

Yang, W. Z., K. A. Beauchemin, and L. M. Rode. 2001b. Effects of grain processing, forage to concentrate ratio, and forage particle size on rumen $\mathrm{pH}$ and extent of digestion by lactating dairy cows. J. Dairy Sci. 84:2203-2216.

Yang, W. Z., K. A. Beauchemin, and L. M. Rode. 2001c. Barley processing, forage:concentrate, and forage length effects on chewing and digesta passage in lactating cows. J. Dairy Sci. 84:2709-2720.

Yang, W. Z., K. A. Beauchemin, and L. M. Rode. 2002. Effects of particle size of alfalfa-based dairy cow diets on site and extent of digestion. J. Dairy Sci. 85:1958-1968. 